\title{
SECURITY, RISK, AND TRUST IN INDIVIDUALS' INTERNET BANKING ADOPTION: AN INTEGRATED MODEL
}

\author{
Chorng-Shyong Ong \\ National Taiwan University \\ No. 1, Sec. 4, Roosevelt Rd., Taipei 10617, Taiwan \\ ongcs@ntu.edu.tw \\ Yi-Luen Lin \\ National Taiwan University \\ No. 1, Sec. 4, Roosevelt Rd., Taipei 10617, Taiwan \\ d99725006@ntu.edu.tw
}

\begin{abstract}
The fact that trust has a specific influence upon individuals' adoption of internet banking has been proven in previous research. However, only few cues about the related evaluation of trust in the online environment are provided and the definition of trust is still ambiguous. Therefore, an integrated SRT (Security-Risk-Trust) model is proposed in this research to explain (1) the relationships among trust and the other highly relevant factors, perceived security and perceived risk; as well as (2) the effects of the above three factors on individuals' adoption of internet banking. An empirical study is accordingly conducted and the data comes from three universities in north Taiwan, and includes 188 students and faculty. Two results are obtained: first is that perceived security is an important antecedent of trust and perceived risk; second is that perceived security has both direct and indirect effects upon individuals' adoption of internet banking. Hence, we suggest that the management of internet banking should put more emphasis on implementing novel information security mechanisms and marketing methods to increase individuals' perceived security, which is crucial to their internet banking adoption.
\end{abstract}

Keywords: Trust, Perceived Security, Perceived Risk, Internet Banking Adoption 


\section{INTRODUCTION}

Banking services play a crucial role in modern society. With rapid and rising development of the Internet, service channels of traditional banks have broadened to the Internet. According to GIA estimation ${ }^{1}$, the number of the global users of internet banking will reach to 657.2 million by 2015 , which shows that internet banking will become a significant channel for existing banks. Therefore, the motivation of this research is to determine the factors that influence individuals' internet banking adoption. Given that banking services are highly involved with sensitive information such as finance, privacy, and transactions, the issues about the safety of the sensitive information like security, risk, and trust, can be regarded as the main consideration of individuals' internet banking adoption.

In previous research, trust has been seen as an important factor that has decisive influence on individuals' adoption of online services ${ }^{2,3,4,5,6,7,8}$. Under this condition, individuals' trust in internet banking determines their adoption $^{9,10,11,12}$. Nevertheless, relevant evaluation and definition of trust in the online environment are indefinite ${ }^{13}$. For example, McKnight et al. ${ }^{14}$ posited structural assurance trust as the security for guarantees, safenets, or other objective structure in a special context, which implies the intensive association between trust and security. Furthermore, Mayer et al. ${ }^{15}$ defined trust as "the willingness of a party to rely on the actions of another party even in the unmonitored circumstances which may lead to the damage of the Trustor" (p. 712). The argument suggests the high involvement between trust and risk.

Despite the above trust-related statements, seldom research simultaneously covers and studies the issue of trust and the other two factors, risk and security. In addition, Lichtenstein and Williamson ${ }^{16}$ and Zhao et al. ${ }^{9}$ argued that risk has effects on individuals' internet banking adoption, while an InsightXplorer investigation assumed that security has the same influence ${ }^{17}$. Therefore, an integrated SRT (Security-Risk-Trust) model is proposed to determine (1) the relationships among security, risk, and trust, as well as (2) the effects of the above three factors upon individuals' internet banking adoption.

The remainder of this research will be organized as follows. Section 2 offers the theoretical foundation of the SRT model. Section 3 gives the description of the research methodology and the empirical results. Section 4 demonstrates the theoretical and practical implications, limitations, and future research. The last section presents the conclusion. 


\section{THEORETICAL BACKGROUND}

\subsection{Trust}

Primitive research of online trust in 1990s mostly focused on the definitions and the constructs ${ }^{14,15}$. With the increasing growth of the Internet, a great diversity of online service has been shown. Limited by spatial and temporal separation, trust between internet service providers and users is hardly to be built through virtual interaction. To respond to this tendency, trust-related research turned to two directions: (1) to determine the antecedents of trust within online service to strengthen trust ${ }^{3,4,5}$, and (2) to study the applications of trust for the online services like e-commerce ${ }^{2,6}$, ${ }^{8}$, online investment ${ }^{7}$, knowledge sharing ${ }^{18}$, and internet banking ${ }^{9,10,11,12}$.

Ability, benevolence, and integrity are proposed as the fundamental facets of trust ${ }^{15}$. Later research separated the concept of trust into two parts: trusting beliefs and trusting intention ${ }^{14}$. Moreover, the combination of the mentioned research for the definition of trust is broadly adopted in diverse domains of the online environment ${ }^{8,9,12,19,20}$. In this research, therefore, trust is defined as an individual's belief in ability, benevolence, and integrity to an internet bank. These three dimensions are also applied in the measurement items of trust.

In the internet banking sector, trust has been proven as a major factor of individuals' internet banking adoption ${ }^{9,10,11,12}$. Different from traditional banking, internet banking has certain difficulties in establishing individuals' trust in the lack of physical contact and face-to-face service. Consequently, trust can only be formed through individuals' reliance on the accomplishment of transactions and the confidentiality of sensitive information. Once trust is set up, individuals will have faith in an internet bank's capability to perform the transactions properly, as well as in its willingness to follow the obligations and in its discipline to avoid opportunistic behaviors. Hence, more individuals have the intention to adopt an internet banking platform. The hypothesis is proposed as follows:

$\mathrm{H} 1$ : Trust is positively related to internet banking adoption.

\subsection{Risk}

Risk, defined as the uncertainties of the results beyond an individual's view or control, may lead to damage. Due to the open nature of the online environment, individuals are exposed to threats of malicious attacks. Likewise, Featherman and Pavlou ${ }^{21}$ proposed specific risk-related constructs that influence individuals' adoption of online services. Before the initiation of internet banking adoption, individuals expressed a great concern about all 
sorts of risks, such as the uncontrollable domination of sensitive information $^{9,19,22,23,24}$.

Accordingly, the next question is how to evaluate risk. Risk cannot be easily captured via objective indicators. For example, there is no absolute linear relationship between the quantity of disclosed privacy of an individual and his perceived level of risk. Here, a subjective term called perceived risk is adopted to describe risk, and its definition, the potential of loss in internet banking adoption, is revised from the previous research ${ }^{25}$. Furthermore, what we focus on in perceived risk are its privacy, finance, performance, and security.

The strong parallel between risk and trust can be traced from their association with the estimation of uncertainties while their indistinct relationship needs to be resolved. Corbitt et al. ${ }^{2}$ argued that perceived risk has negative effects on trust. In addition, prior research also claimed that

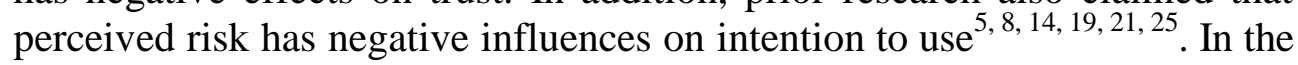
internet banking context, high perceived risk will not only reduce individuals' trust upon internet banking, but will also lessen their willingness to adopt internet banking with the concern of high potential loss ${ }^{9,16}$. Hence, we propose hypotheses as follows:

$\mathrm{H} 2$ : Perceived risk is negatively related to internet banking adoption.

H3: Perceived risk is negatively related to trust.

\subsection{Security}

Security is a major concern that contributes to an individuals' desire to adopt online services ${ }^{26,27}$, because security events, ranging from privacy disclosure to financial loss, may cause certain damage to individuals whose willingness to apply online service is thus lessened. In this case, the enhancement of security for the services provided by online service providers would be helpful to reduce the service uncertainties, decreasing perceived risk ${ }^{2}$, and even increasing trust ${ }^{7,25,28,29}$ as well as adoption rates.

In the process of evaluating security, objective indicators, such as investment in security equipment, cannot be the embodiment of the subjective measurement within individuals. Therefore, the term perceived security, adapted from the prior research ${ }^{29}$ is applied to illustrate the concepts of security and is revised as "the subjective probability with which people believe their sensitive information will not be viewed, stored or manipulated during transit or storage by inappropriate parties, in manner consistent with their confident expectations." 
Like trust and perceived risk, perceived security is an important factor that influences individuals' internet banking adoption ${ }^{23,24,30}$. The implementation of novel information security mechanisms could prevent an internet bank from malicious attacks, ensure the confidentiality of the sensitive information, and perform the transactions properly. Consequently, individuals' anxieties toward risk will be reduced and their internet banking adoption will be increased through their belief in the ability, the benevolence, and the integrity of an internet bank to finish the transaction ${ }^{29}$. The hypotheses are proposed as follows and the SRT model is illustrated as Figure 1.

H4: Perceived security is positively related to internet banking adoption.

H5: Perceived security is positively related to trust.

H6: Perceived security is negatively related to perceived risk.

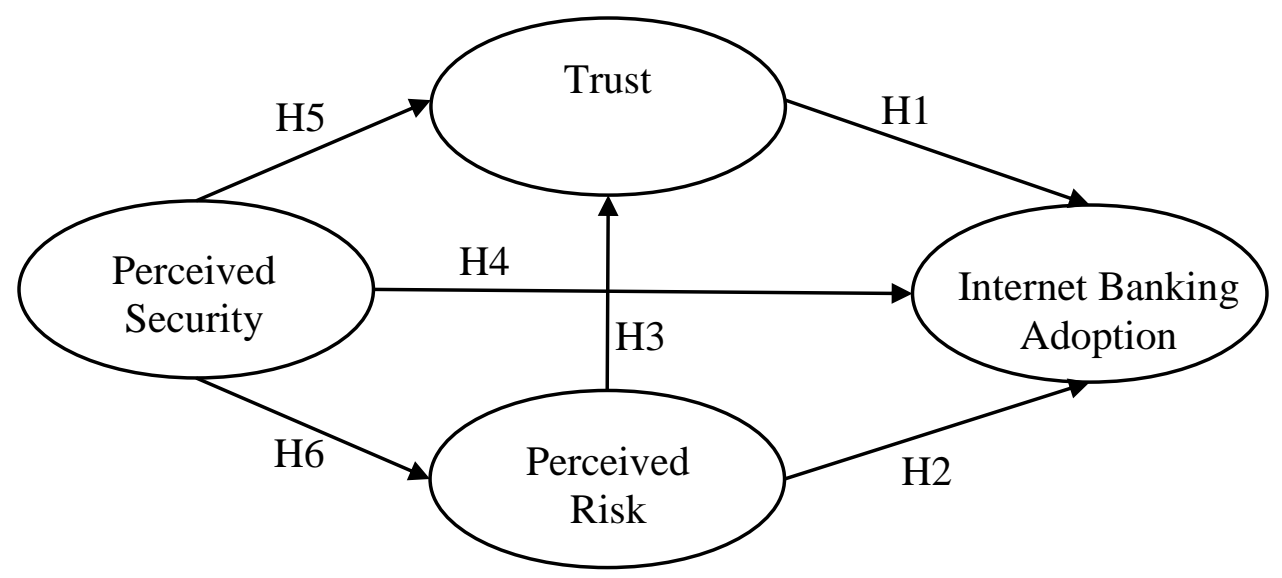

Figure 1. SRT Model

\section{RESEARCH METHODOLOGY}

\subsection{Instrument Development}

The items are adapted from the previous research and the details are presented in the Appendix. A Likert 7-point scale is adopted for all measures, ranging from strongly disagree (1) to strongly agree (7). For the consideration of face validity, three Ph.D. students are consulted to check the description of the survey items.

\subsection{Data Collection}

Three hundred sixty-two questionnaires were distributed to the students and the faculty of three universities in north Taiwan. Excluding the respondents without internet banking adoption and unqualified 
questionnaires (e.g., all items were filled in 7), 188 questionnaires were valid (response rate is $51.93 \%$ ). The internet bank mainly used by each respondent was designed as the target, which included Chunghwa Post (34), Chinatrust Commercial Bank (26), Bank Of Taiwan (23), Hua Nan Commercial Bank (22), and Cathay United Bank (20). All the details of descriptive statistics are presented in Table 1.

Table 1. Descriptive Statistics of the Respondents

\begin{tabular}{cccc}
\hline Measure & Items & Freq. & Percent \\
\hline Gender & Male & 107 & 56.91 \\
& Female & 81 & 43.09 \\
Internet Banking Experience & $<1$ & 58 & 30.85 \\
(in years) & $1-2$ & 59 & 31.38 \\
& $\geqq 3$ & 71 & 37.77 \\
Internet Banking Frequency & $<1$ & 19 & 10.11 \\
(per month) & $1-2$ & 93 & 49.47 \\
& $3-5$ & 43 & 22.87 \\
& $\geqq 6$ & 33 & 17.55 \\
Age & $\leqq 20$ & 28 & 14.89 \\
& $21-25$ & 50 & 26.60 \\
& $26-30$ & 38 & 20.21 \\
& $31-35$ & 37 & 19.68 \\
Education & $36-40$ & 21 & 11.17 \\
& $\geqq 41$ & 14 & 7.45 \\
& Senior High School & 4 & 2.13 \\
& College \& University & 127 & 67.55 \\
Graduate School & 57 & 30.32 \\
\hline
\end{tabular}

\subsection{Structure Model}

The software SmartPLS 2.0 M3 with 500 bootstrapping samples broadly applied to the quantitative research in the information management field $^{20}$ is used to analyze the proposed model. First, we consider the composite reliability of the instrument and then drop the items with cross loading smaller than 0.6. The deleted items of trust approximate to the prior research ${ }^{8}$. Accordingly, the values of composite reliability among the constructs are greater than 0.7, the values of Cronbach's $\alpha$ are greater than 0.8 , and the values of AVE are greater than 0.6. The descriptive statistics, correlation, and cross loading of the constructs are presented in Table 2, 3, and 4 , respectively. 
Table 2. Descriptive Statistics among Constructs

\begin{tabular}{ccccccc}
\hline & Items & Mean & S. D. & Cronbach's $\alpha$ & $\begin{array}{c}\text { Composite } \\
\text { Reliability }\end{array}$ & AVE \\
\hline $\begin{array}{c}\text { Internet Bank } \\
\text { Adoption (IBA) }\end{array}$ & 4 & 5.29 & 1.07 & 0.95 & 0.97 & 0.87 \\
$\begin{array}{c}\text { Perceived Risk } \\
\text { (PR) }\end{array}$ & 9 & 3.38 & 1.33 & 0.92 & 0.93 & 0.60 \\
$\begin{array}{c}\text { Perceived Security } \\
\text { (PS) }\end{array}$ & 4 & 4.81 & 1.28 & 0.95 & 0.97 & 0.87 \\
Trust (TU) & 4 & 4.71 & 1.10 & 0.83 & 0.89 & 0.66 \\
\hline
\end{tabular}

Table 3. Correlation among Constructs

\begin{tabular}{ccccc}
\hline & IBA & PR & PS & TU \\
\hline IBA & $\mathbf{0 . 9 4}$ & & & \\
PR & -0.41 & $\mathbf{0 . 7 7}$ & & \\
PS & 0.49 & -0.48 & $\mathbf{0 . 9 3}$ & \\
TU & 0.51 & -0.44 & 0.67 & $\mathbf{0 . 8 1}$ \\
\hline
\end{tabular}

Note: The bold is the square root of the AVE.

Table 4. Cross Loadings among Items

\begin{tabular}{ccccc}
\hline Items & IBA & PR & PS & TU \\
\hline IBA1 & $\mathbf{0 . 9 2}$ & -0.37 & 0.46 & 0.48 \\
IBA2 & $\mathbf{0 . 9 5}$ & -0.40 & 0.47 & 0.51 \\
IBA3 & $\mathbf{0 . 9 4}$ & -0.37 & 0.42 & 0.43 \\
IBA4 & $\mathbf{0 . 9 4}$ & -0.38 & 0.48 & 0.49 \\
PR1 & -0.21 & $\mathbf{0 . 6 1}$ & -0.13 & -0.12 \\
PR2 & -0.32 & $\mathbf{0 . 7 1}$ & -0.20 & -0.20 \\
PR3 & -0.27 & $\mathbf{0 . 7 6}$ & -0.27 & -0.31 \\
PR4 & -0.22 & $\mathbf{0 . 8 1}$ & -0.34 & -0.31 \\
PR5 & -0.38 & $\mathbf{0 . 8 8}$ & -0.53 & -0.45 \\
PR6 & -0.38 & $\mathbf{0 . 8 9}$ & -0.50 & -0.46 \\
PR7 & -0.35 & $\mathbf{0 . 8 1}$ & -0.37 & -0.37 \\
PR8 & -0.25 & $\mathbf{0 . 6 3}$ & -0.17 & -0.16 \\
PR13 & -0.36 & $\mathbf{0 . 8 0}$ & -0.50 & -0.41 \\
PS1 & 0.47 & -0.44 & $\mathbf{0 . 9 4}$ & 0.64 \\
PS2 & 0.49 & -0.50 & $\mathbf{0 . 9 4}$ & 0.64 \\
PS3 & 0.44 & -0.45 & $\mathbf{0 . 9 3}$ & 0.64 \\
PS4 & 0.44 & -0.40 & $\mathbf{0 . 9 3}$ & 0.58 \\
TU1 & 0.46 & -0.42 & 0.58 & $\mathbf{0 . 8 8}$ \\
TU2 & 0.35 & -0.34 & 0.49 & $\mathbf{0 . 8 3}$ \\
TU3 & 0.37 & -0.30 & 0.53 & $\mathbf{0 . 7 7}$ \\
TU6 & 0.47 & -0.35 & 0.55 & $\mathbf{0 . 7 7}$ \\
\hline
\end{tabular}


Figure 2 illustrates the results for the SRT model, and the hypotheses 1 to 6 are all supported. Perceived security has direct and indirect effects (via perceived risk and trust) upon internet banking adoption. Also, perceived security has strong and direct effects on trust, and it has indirect influence on trust by reducing perceived risk. Trust is well interpreted by the relationship among perceived security and perceived risk $\left(R^{2}=0.46\right)$. In addition, perceived security has strong effects on reducing perceived risk. Therefore, perceived security is deduced to be the important antecedent of perceived risk and trust.

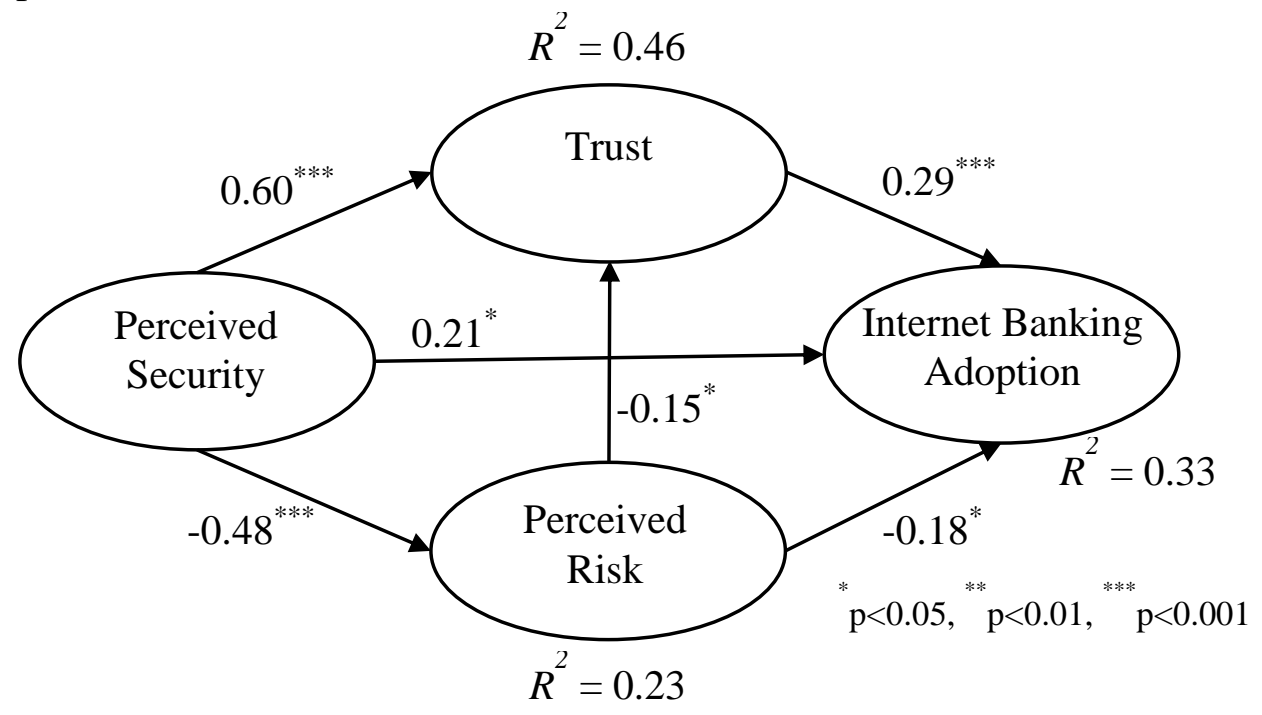

Figure 2. Results for SRT model

\section{IMPLICATIONS}

\subsection{Implication for Theory}

In previous research, trust has been proven to be one of the important antecedents for individuals to adopt internet banking $9,10,11,12$, and it is highly relevant with risk and security. However, the relationships among them are not stated very clearly. In this research, perceived security is the fundamental antecedent of trust, risk, and internet banking adoption. Perceived risk and trust are the mediators between perceived security and internet banking adoption. Moreover, perceived risk is a significant predecessor of trust and internet banking adoption.

\subsection{Implication for Practice}

Highly perceived security not only reduces an individual's perceived risk but also enhances his trust in the internet banking context, which allows for a higher adoption rate. Since perceived security plays such an important 
role for individuals to adopt internet banking, the management of internet banking should pay more attention to strengthen individuals' perceived security, such as implementing novel information security mechanisms and marketing methods. For example, an internet bank can implement 1024-bit public key algorithm to reveal digital signature, or apply a SHA-2 hash function to prevent the transmitted message from altering. It's worth mentioning that implementing security technologies is the first step, while the second step is to demonstrate the function and protection of these mechanisms to individuals. The technical statement of security technologies should be concise and precise for individuals whose perceived security is thus possibly strengthened.

\subsection{Limitations and Future Research}

The general concepts for individuals to adopt internet banking have been taken into discussion in this research. In consideration of internet banking diversities, however, the target could be focused on specific internet banks. In addition, the expertise of the Internet or information technology may have influence on perceived security, perceived risk, and trust in internet banking. During our interview, for example, a respondent who was an IT professional directly expressed his distrust in internet banking, which can be compromised anytime. Consequently, the consideration of IT expertise should be included in future research.

Trust in the brand of a bank is relevant with its internet banking service; individuals may adopt specific internet banking due to the physical bank's reputation. Here, it is an interesting question to distinguish the transference of brand effects from physical banks to their internet banking. Beyond internet banking adoption, how to keep customers using internet banking is the next question. Therefore, continued usage of internet banking and its antecedents should be determined.

\section{CONCLUSIONS}

We propose an integrated model, called the SRT model, to illustrate the relationships among perceived security, perceived risk, and trust, as well as the effects of those factors on individuals' internet banking adoption. The empirical study shows that perceived security is the important antecedent of trust and perceived risk, and it is highly involved with them. In this regard, security should be considered in trust and risk related research. Meanwhile, perceived security is also a vital factor that influences individuals to adopt internet banking. Hence, the management of internet banking should put more emphasis on how to increase individuals' perceived security. 


\section{REFERENCES}

[1] Global Industry Analysts, Global internet banking customer base to reach 657.2 million by 2015. Retrieved on March 25, 2013, from http://www.prweb.com/releases/internet_banking/online_banking/prwe b3453104.htm.

[2] B.J. Corbitt, T. Thanasankit, and H. Yi, Trust and e-commerce: A study of consumer perceptions. Electronic Commerce Research and $\begin{array}{lll}\text { Applications, } & \text { 2(3), } 2003 .\end{array}$ http://dx.doi.org/10.1016/S1567-4223(03)00024-3.

[3] D. Gefen, and D.W. Straub, Consumer trust in B2C e-commerce and the importance of social presence: Experiments in e-products and e-services. Omega, 32(6), p407-424, 2004. http://dx.doi.org/j.omega.2004.01.006.

[4] D. Gefen, E. Karahanna, and D.W. Straub, Trust and TAM in online shopping: An integrated model. MIS Quarterly, 27(1), p51-90, 2003.

[5] D.J. Kim, D.L. Ferrin, and H.R. Rao, A trust-based consumer decision-making model in electronic commerce: The role of trust, perceived risk, and their antecedents. Decision Support Systems, 44(2), p544-564, 2008. http://dx.doi.org/10.1016/j.dss.2007.07.001.

[6] P.A. Pavlou, H. Liang, and Y. Xue, Understanding and mitigating uncertainty in online exchange relationships: A principal-agent perspective. MIS Quarterly, 31(1), p105-136, 2007.

[7] S. Balasubramanian, P. Konana, and N.M. Menon, Customer satisfaction in virtual environments: A study of online investing. $\begin{array}{lll}\text { Management } \quad \text { Science, } & \text { 49(7), } & \end{array}$ http://dx.doi.org/10.1287/mnsc.49.7.871.16385.

[8] S.L. Jarvenpaa, N. Tractinsky, and M. Vitale, Consumer trust in an internet store. Information Technology and Management, 1(1-2), p45-71, 2000.

[9] A.L. Zhao, N. Koenig-Lewis, S. Hanmer-Lloyd, and P. Ward, Adoption of internet banking services in China: Is it all about trust? International Journal of Bank Marketing, 28(1), p7-26, 2010. http://dx.doi.org/10.1108/02652321011013562.

[10] A. Y.-L. Chong, K.-B. Ooi, B. Lin, and B.-I. Tan, Online banking adoption: An empirical analysis. International Journal of Bank Marketing, 28(4), p267-287, 2010. http://dx.doi.org/10.1108/02652321011054963.

[11] S.M. Huang, W.C. Shen, D.C. Yen, and C.L. Yi, IT governance: Objectives and assurances in internet banking. Advances in Accounting, 27(2), p406-414, 2011. http://dx.doi.org/10.1016/j.adiac.2011.08.001.

[12] S.Y. Yousafzai, J.G. Pallister, and G.R. Foxall, Strategies for building and communicating trust in electronic banking: A field experiment. 
Psychology \& Management, 22(2), p181-201, 2005. http://dx.doi.org/10.1002/mar.20054.

[13] M. Lee, and E. Turban, A trust model for consumer internet shopping. International Journal of Electronic Commerce, 6(1), p75-91, 2001. http://dx.doi.org/10.1080/10864415.2001.11044227.

[14] D.H. McKnight, L.L. Cummings, and N.L. Chervany, Initial trust formation in new organizational relationships. The Academy of Management Review, 23(3), p473-490, 1998. http://dx.doi.org/10.5465/AMR.1998.926622.

[15] R.C. Mayer, J.H. Davis, and F.D. Schoorman, An integrative model of organizational trust. The Academy of Management Review, 20(3), p709-734, 1995. http://dx.doi.org/10.5465/AMR.1995.9508080335.

[16] S. Lichtenstein, and K. Williamson, Understanding consumer adoption of internet banking: An interpretive study in the Australian banking context. Journal of Electronic Commerce Research, 7(2), p50-66, 2006.

[17] InsightXplorer, Investigation for financial service usage behavior in Taiwan. Retrieved on March 25, 2013, from http://tw.tranews.com/Show/Style1/News/c1_News.asp?SItemId=0271 $030 \&$ ProgramNo $=\mathrm{A} 000001000004 \&$ SubjectNo $=3273711$.

[18] Y.-H. Chen, T.-P., Lin, and D.C. Yen, How to facilitate inter-organizational knowledge sharing: The impact of trust. Information \& Management, 41(5), p568-578, 2014. http://dx.doi.org/10.1016/j.im.2014.03.007.

[19] A.I. Nicolaou, and D.H. McKnight, Perceived information quality in data exchanges: Effects on risk, trust, and intention to use. Information Systems Research, 17(4), p332-351, 2006.

[20] C.M. Chiu, M.H. Hsu, H.C. Lai, and C.M. Chang, Re-examining the influence of trust on online repeat purchase Intention: The moderating role of habit and its antecedents. Decision Support Systems, 53(4), p835-845, 2012. http://dx.doi.org/10.1016/j.dss.2012.05.021.

[21] M.S. Featherman, and P.A. Pavlou, Predicting e-services adoption: A perceived risk facets perspective. International Journal of Human-Computer Studies, 59(4), p451-474, 2003. http://dx.doi.org/10.1016/S1071-5819(03)00111-3.

[22] M. Sathye, Adoption of Internet banking by Australian consumers: An empirical investigation. International Journal of Bank Marketing, 17(7), p324-334, 1999. http://dx.doi.org/10.1108/02652329910305689.

[23] T.C.E. Cheng, D.Y.C. Lam, and A.C.L. Yeung, Adoption of internet banking: An empirical study in Hong Kong. Decision Support Systems, 42(3), p1558-1572, 2006. http://dx.doi.org/10.1016/j.dss.2006.01.002.

[24] Z. Liao, and M.T. Cheung, Internet-based e-banking and consumer attitudes: An empirical study. Information \& Management, 39(4), 
p283-295, 2002. http://dx.doi.org/10.1016/S0378-7206(01)00097-0.

[25] S.Y. Yousafzai, J.G. Pallister, and G.R. Foxall, A proposed model of e-trust for electronic banking. Technovation, 23(11), p847-860, 2003. http://dx.doi.org/10.1016/S0166-4972(03)00130-5.

[26] O. Tiago, M. Thomas, and M. Espadanal, Assessing the determinants of cloud computing adoption: An analysis of the manufacturing and services sectors. Information \& Management, 51(5), p497-510, 2014. http://dx.doi.org/10.1016/j.im.2014.03.006.

[27] W.D. Salisbury, R.A. Pearson, and D.W. Miller, Perceived security and World Wide Web purchase intention. Industrial Management \& Data Systems, 101(4), p165-177, 2001. http://dx.doi.org/10.1108/02635570110390071.

[28] B. Suh, and I. Han, The impact of customer trust and perception of security control on the acceptance of electronic commerce. International Journal of Electronic Commerce, 7(3), p135-161, 2003. http://dx.doi.org/10.1080/10864415.2003.11044270.

[29] R.K. Chellappa, and P.A. Pavlou, Perceived information security, financial reliability and consumer trust in electronic commerce transactions. Logistics Information Management, 15(5/6), p358-368, 2002. http://dx.doi.org/10.1108/09576050210447046. 


\section{APPENDIX}

\section{Appendix A. Questionnaire Items}

\begin{tabular}{|c|c|c|}
\hline Items & Descriptions & Source \\
\hline IBA1 & Assuming that I have access to internet banking, I intent to use them. & 10 \\
\hline IBA2 & $\begin{array}{l}\text { I intend to use internet banking if the cost and times is reasonable for } \\
\text { me. }\end{array}$ & \\
\hline IBA3 & I believe I will use internet banking in the future. & \\
\hline IBA4 & I intend to increase my use of internet banking in the future. & \\
\hline PS1 & $\begin{array}{l}\text { I would feel secure sending sensitive information (e.g., transaction } \\
\text { information) across this internet bank. }\end{array}$ & 23 \\
\hline PS2 & $\begin{array}{l}\text { This internet bank is a secure means through which to send sensitive } \\
\text { information (e.g., transaction information). }\end{array}$ & \\
\hline PS3 & $\begin{array}{l}\text { I would feel totally safe providing sensitive information about myself } \\
\text { over this internet bank. }\end{array}$ & \\
\hline PS4 & $\begin{array}{l}\text { Overall, this internet bank is a safe place to transmit sensitive } \\
\text { information (e.g., transaction information). }\end{array}$ & \\
\hline PR1 & I will lose money. & 9 \\
\hline PR2 & I will lose control of my bank account. & \\
\hline PR3 & My money loss will not be covered by this internet bank. & \\
\hline PR4 & Others will know my personal details. & \\
\hline PR5 & Others will misuse my data. & \\
\hline PR6 & I will lose control of my personal data. & \\
\hline PR7 & This internet bank will not work as I expect. & \\
\hline PR8 & This internet bank will have technical problems. & \\
\hline PR9 & $\begin{array}{l}\text { I will have to be careful when I use this internet bank because I need } \\
\text { to ensure I don't make mistakes.* }\end{array}$ & \\
\hline PR10 & Fake internet banking web servers may be shown online.* & \\
\hline PR11 & This internet bank can be attacked.* & \\
\hline PR12 & This internet bank will not work properly.* & \\
\hline PR13 & This internet bank is not secure. & \\
\hline TU1 & This internet bank is trustworthy. & 8 \\
\hline TU2 & $\begin{array}{l}\text { This internet bank wants to be known as one who keeps promises and } \\
\text { commitments. }\end{array}$ & \\
\hline TU3 & I trust this internet bank keeps my best interests in mind. & \\
\hline TU4 & I find it necessary to be cautious with this internet bank. [reverse]* & \\
\hline TU5 & $\begin{array}{l}\text { This internet bank has more to lose than to gain by not delivering on } \\
\text { their promises.* }\end{array}$ & \\
\hline TU6 & This internet bank's behavior meets my expectations. & \\
\hline TU7 & $\begin{array}{l}\text { This internet bank could not care less about servicing a person from } \\
\text { Taiwan. [reverse]* }\end{array}$ & \\
\hline
\end{tabular}


